\title{
前垂れによる栈橋上部エコンクリートへの 塩分供給量の低減効果に関する現地実験
}

\author{
武田 将英 1 -下迫 健一郎 2 - 山路 徹 3 - 羽㴊 貴士 $4 \cdot$ \\ 網野 貴彦 4 - 花岡 大伸 4 -津田 宗男 4 \\ 1正会員 東亜建設工業株式会社 土木事業本部設計部 \\ （１02-8451 東京都新宿区西新宿3-7-1＼cjkstart新宿パークタワー31F） \\ E-mail:m_takeda@toa-const.co.jp \\ 2正会員 (独法)港湾空港技術研究所 海洋研究領域長 ( \\ E-mail: shimosako@pari.go.jp \\ 3正会員 (独法)港湾空港技術研究所 構造研究領域長（广239-0826 神奈川県横須賀市長瀬3-1-1） \\ E-mail: yamaji@pari.go.jp \\ 4正会員 東亜建設工業株式会社＼cjkstart技術研究開発センター（†230-0035 横浜市鶴見区安善町1-3）
}

\begin{abstract}
港湾構造物の中でも栈橋上部工は, 塩害による早期劣化が維持管理上の大きな問題になっている. 本研 究では，栈橋下面での砕波の発生回数すなわち海水飛沫の発生量を低減する目的で，実際の栈橋において， 設置高さの異なるカーテンウォール状の前垂れを複数配置した. その背後の梁と床板にコンクリート供試 体を設置し, 海洋環境下での曝露を 2 年間行い, 曝露開始 1 年目と 2 年目に曝露供試体を回収した. 曝露 供試体の塩化物イオン濃度測定結果から，前垂れ設置による塩分供給量の低減効果について検討を行った.

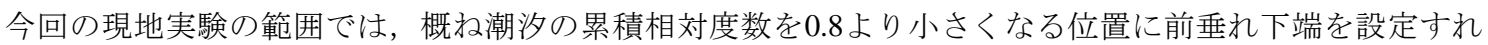
ば，塩分供給量の低減効果が得られることが分かった。
\end{abstract}

Key Words : curtain wall, chloride ion, concrete structure, marine environment, cumulative relative frequency of tidal height

\section{1. はじめに}

国土交通白書 ${ }^{1)}$ にると，我が国では，高度成長期以 降に整備したインフラが急速に老朽化し，今後 20 年間 で建設後 50 年以上経過する施設の割合が加速度的に高 くなる見込みである，例えば，水深-4.5m 以深の港湾岸 壁では，その割合が 2012年 3 月で 7\%から，2022年 3 月 で 29\%，2032年 3 月で 56\%と急増する．そのため，これ ら急速に老朽化が進むインフラを戦略的に維持管理・更 新することが求められている.

大即ほか ${ }^{22} は ， 1980$ 年代に全国の約 500 の係船岸を対 象とした目視調查を行い，港湾のコンクリート構造物で は，栈橋上部工の塩害による劣化が著しいと報告してい る. また, 現代においても, 栈橋上部工の塩害劣化は, 維持管理上の大きな問題であることに変わりはない，網 野ほか ${ }^{3}$ は，栈橋上部工一の塩分供給量は部材の空間的 な位置や構造条件, 波浪条件等によって大きく異なるこ とを明らかとした，その中で，栈橋上部工にカーテンウ オール状の構造部材である「前垂れ」が存在する場合に
は，栈橋下面への波の進入が抑制されることで，コンク リート部材中への塩分供給量も抑制される傾向があるこ とを確認している.

この前垂れの存在による塩分供給量の抑制についての メカニズムについてはまだ十分には明らかになっていな

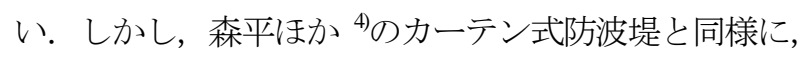

「前垂れ」が栈橋に作用寸る不規則な波の周期の短い波 動成分を栈橋前面で部分反射させて，栈橋上部工の下に 到達する波のうち，波形勾配が大きくなりやすい周期の 短い波動成分の振幅を低減する。そ結果, 砕波の発生 回数すなわち海水飛沫の発生量を少なくし，コンクリー 卜中への塩分供給量の低減がなされているものと考えら れる.

そこで，本研究では，実際の栈橋において，設置高さ の異なる前垂れを複数配置し，その背後に暴露したコン クリート供試体の塩化物イオン濃度の測定結果から, 前 垂れ設置による塩分供給量の低減効果について検討を行 った. また，前垂れ設置高さによる波浪の変化を取得す るため，栈橋下での波浪観測もあわせて行った. 


\section{2. 現地実験の内容}

\section{(1) 前垂れの構造}

「前垂れ」とは，栈橋の倸船面に配置される上部工の 梁下端よりもさらに垂下した板部材のことを指寸。これ らは，主として，防舷材を取り付けるためや栈橋下一の

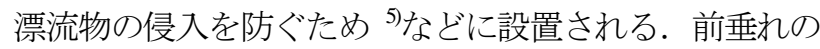
ある栈橋では，通常は建設時に係船面の梁と一体となる ように，鉄筋コンクリートで前垂れを作ることが多い. しかし, 本研究では, 既設栈橋を対象としたため, 後付 けで前垂れを設置した。

前垂れには，強度と而久性に優れた材料である UHPSHCC (Ultra High Performance-Strain Hardening Cementitious Composite : 超高強度繊維補強モルタル）のの厚さ $0.03 \mathrm{~m}$ ×横 $2.1 \mathrm{~m} \times$ 縦 $1.00 \mathrm{~m} ， 0.75 \mathrm{~m} ， 0.50 \mathrm{~m}$ のプレキャスト板を 用いた。 これは，海水による材料劣化だけでなく波浪や 漂流物等による外力に耐えうるためである.

\section{（2） 前垂れの設置場所 · 設置方法}

現地実験は，図-1～図-3 に示寸神奈川県横須賀市追浜 にある東亜建設工業（株）所有の栈橋（延長 $139.7 \mathrm{~m}$ ） で行った，本栈橋は，海から栈橋を見て，左側が重量栈 橋（延長 $78.15 \mathrm{~m}$ ，前面水深 $4.0 \mathrm{~m}$ ），右側が軽量栈橋 （延長 $61.55 \mathrm{~m}$, 前面水深 $5.0 \mathrm{~m}$ ) でいずれも護岸と平行 につくられる横栈橋となっている，今回の実験では，重
量栈橋の図-2，図-3 に示寸位置における栈橋上部工の前 面に前垂れを設置した．また，前垂れの設置高さ（海水

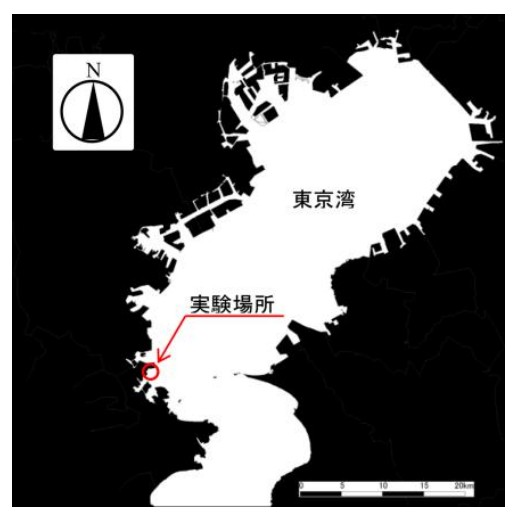

図-1 実験場所

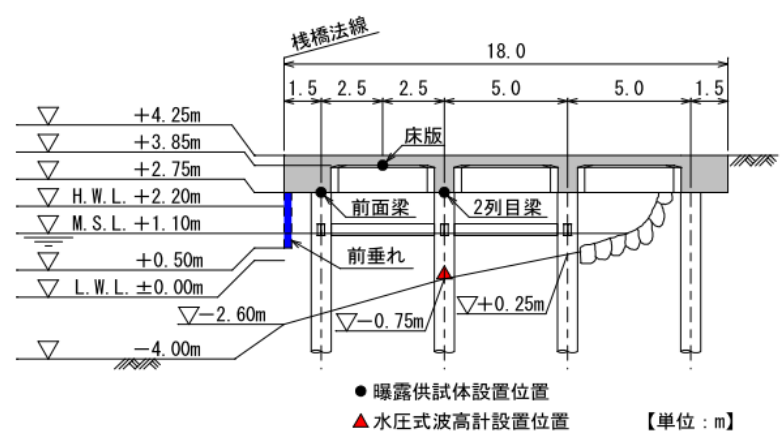

図-2＼cjkstart前垂れ断面図（前垂れ下端高さ+0.5m）

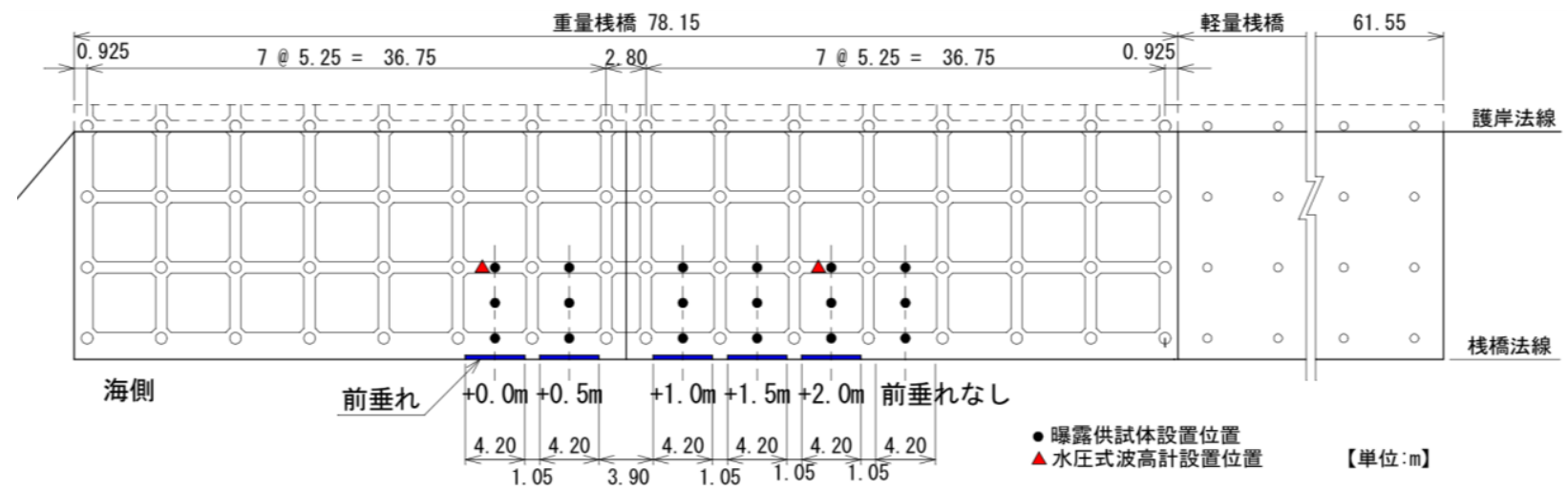

(a) 平面図

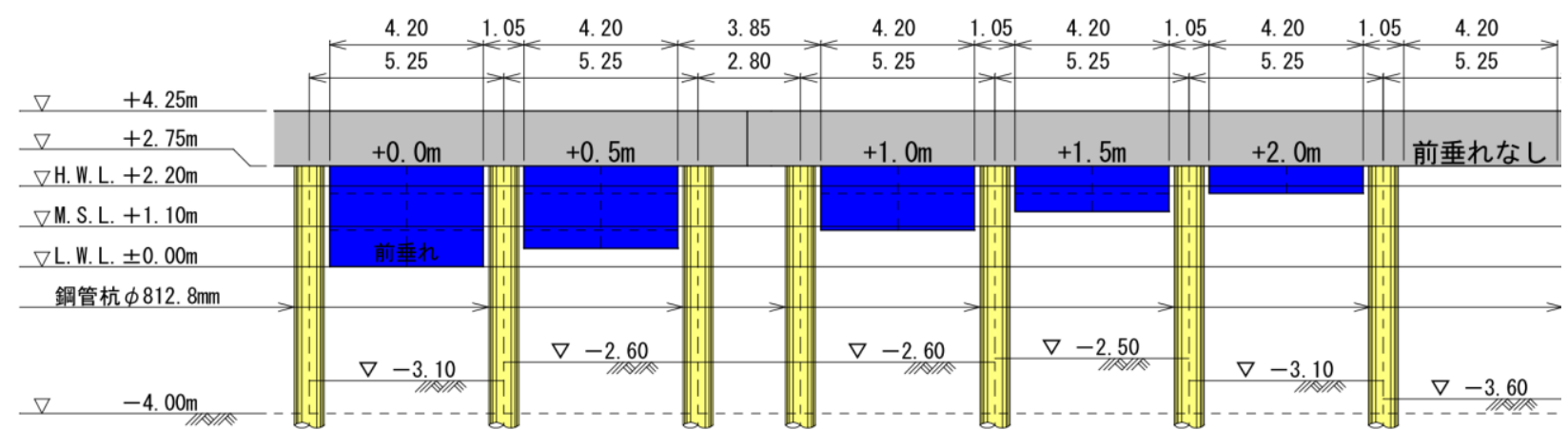

(b) 正面図

図-3＼cjkstart前垂れおよび曝露供試体の設置位置 


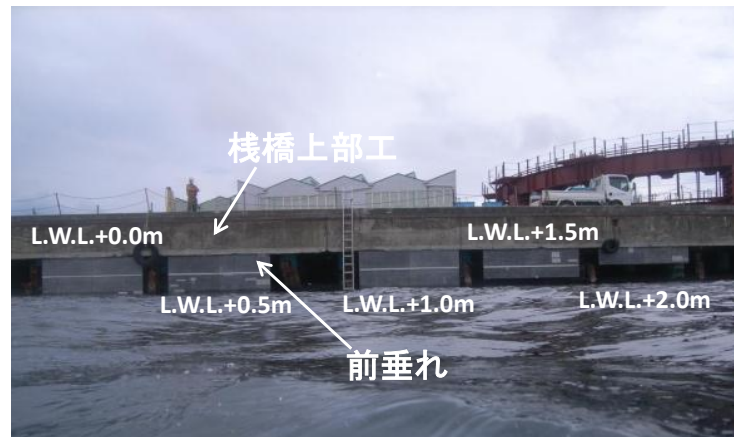

図-4 前垂れの設置状況

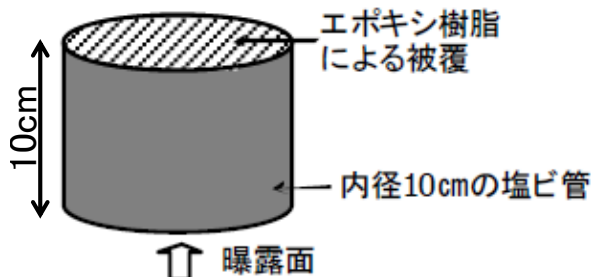

図-5 曝露供試体の概要

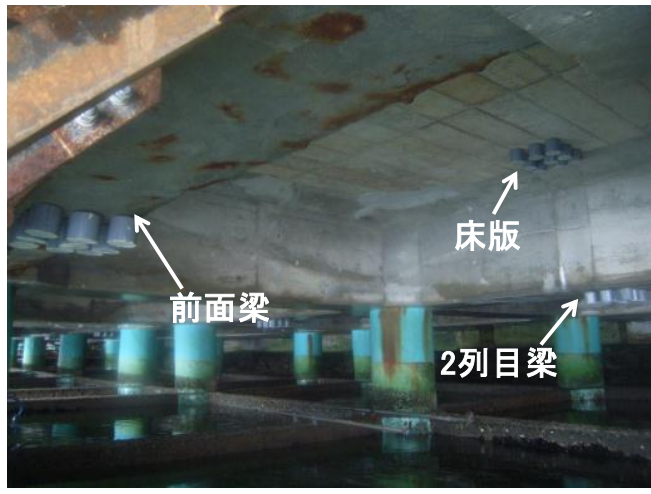

図-6 供試体の曝露状況

表-1＼cjkstart曝露供試体の配合

\begin{tabular}{c|c|c|c|c|c|c|c}
\hline \multirow{2}{*}{$\begin{array}{c}\text { W/C } \\
(\%)\end{array}$} & \multirow{2}{*}{$\begin{array}{c}\text { Sa } \\
(\%)\end{array}$} & \multirow{2}{*}{$\begin{array}{c}\text { Air } \\
(\%)\end{array}$} & \multicolumn{6}{|c|}{ 単位量 $\left(\mathrm{kg} / \mathrm{m}^{3}\right)$} \\
\cline { 5 - 8 } & & $\mathrm{W}$ & $\mathrm{C}$ & $\mathrm{S}$ & $\mathrm{G}$ & $\begin{array}{c}\mathrm{AE} \\
\text { 減水剂 }\end{array}$ \\
\hline \hline 55.0 & 43.7 & 4.5 & 165 & 300 & 806 & 1040 & $\mathrm{C} \times 0.4 \%$ \\
\hline
\end{tabular}

*普通ポルトランドセメント, $\mathrm{AE}$ 減水剤標準型 I 種を仕様

面から前垂れ下端までの高さ）による塩分供給量の違い を把握するため，前垂れの下端高さは，図-3 に示すよ うに, L.W.L.より+0.0m (L.W.L), +0.5m, +1.0m, +1.5m, +2.0m (H.W.L.)の 5 ケースとした. なお，図-3に示すよう に隣り合う前垂れの間は $1.05 \mathrm{~m}$ 離れているが，この間に は鋼管杭 $\phi 812.8 \mathrm{~mm}$ が存在する.ただし，前垂れ設置高 さ L.W.L+0.5m と L.W.L+1.0m の間には，同径の鋼管杭が 2 本存在し，その杭間には約 $2.0 \mathrm{~m}$ の前垂れがない開口部 が存在する。また，図-2, 図-3 には，以降に説明する曝 露供試体の設置位置, 並びに波高計の設置位置もあわせ
て記載してある.さらに，図-3 には，現地で測深した 前面梁中央部における水深も示すが， L.W.L.-3.6m〜$2.5 \mathrm{~m}$ と少しばらつきがみられた。

既設栈橋への前垂れの固定方法は，製作したプレキャ スト板に鋼製のブラケットを取付け，そのブラケットを 栈橋上部工の下面にアンカーで固定して行った. 今回は, 栈橋法線と前垂れの係船側のコンクリート面は段差がな いように設置した. 図-4に前垂れの設置状況を示す.

\section{(3) 曝露試験体の概要}

本研究では，図-2，図-3 に示す前垂れを設置した背面 および前垂れを設置していない栈橋上部工の所定の位置 に，図-5に示寸曝露供試体を 1 か所あたり 9個設置し， 海洋環境下における曝露を実施した。供試体の曝露状況 を図-6 に示す。また，図-5 に示す曝露供試体は，内径 $0.10 \mathrm{~m}$, 高さ $0.10 \mathrm{~m}$ の塩ビ管の中にコンクリートを打設 したものである. いずれの供試体も表-1 に示す同一配 合のコンクリート（水セメント比 $\mathrm{W} / \mathrm{C}=0.55$, 普通ポル トランドセメント使用）を使用した。また，供試体の下 面に位置する曝露面以外からの塩分供給を防ぐため, 供 試体の上面はエポキシ樹脂で被覆してある.

曝露 1 年目と 2 年目に，供試体を 1 か所あたり 3 個ず つ回収し，供試体中に浸透した塩化物イオン濃度を測定 することで，前垂れ設置による塩分供給量の低減効果を 把握した.

\section{3. 前垂れの設置高さと塩化物イオン濃度の関係}

\section{(1) 塩化物イオン濃度の測定方法}

回収した供試体は，曝露面から深さ $3 \mathrm{~cm}$ ま゙を $1 \mathrm{~cm}$ 幅 で切り出し，各々の試験片に含まれる全塩化物イオン濃 度を「JIS A 1154 硬化コンクリート中に含まれる塩分の 分析方法 : 硝酸銀滴定法」に準じて測定した.

(2) 前垂れ高さと塩化物イオン濃度の関係

\section{a) 塩化物イオン濃度の測定結果}

曝露表面から深さ $1 \mathrm{~cm}$ までのスライス片における塩 化物イオン濃度 $C_{10}$ と前垂れ設置高さとの関係を図-7に 示す. この塩化物イオン濃度 $C_{10}$ は, 供試体 3 本の平均 值を示す.

梁下に設置したものと（前面梁·2 列目梁）と床版に 設置したものを比較すると，前垂れの有無によらず，梁 下の方が床版よりも塩分の浸透が多いことが理解できる. これは，大即ほか ${ }^{20} の$ 目視調査結果である「桁や梁は， 平均海面上 $1 \mathrm{~m}$ 程度に位置し，絶えず波しぶきにさらさ れている.このため, 他の部材に比較して塩害を受けや すいと考えられる。一方，床板は桁よりも，1m 程度上 
方に位置し，桁よりは塩害を受けにくい傾向がある」と 同様の傾向がみられた.

前面梁および 2 列目梁では, 概小 L.W.L.+0.5m よりも 前垂れの設置高さを低くすると, 塩化物イオン濃度が低 減する傾向が見られた．また，前面梁と2列目梁とでは, 2 列目梁の方が相対的に小さい值となったが，この要因 については，必ずしも特定できていないが，現地におい て実測した前面梁の位置における水深（L.W.L.-3.6m〜 $2.5 \mathrm{~m})$ と 2 列目梁における水深（L.W.L.-0.85m〜-0.55m) に大きな違いがみられることや，2 列目梁の場合には， 水深 L.W.L.1.13m の位置に杭頭を結合するためのブレス 材(H-482x300)が 1 列目と 2 列目の杭の位置に配置（図-2, 図-6 参照) されており，これも前垂れと同様に波を部 分反射させる効果があった可能性が考えられる.

床版に曝露した供試体の結果は, 梁下のものに比べて 表面塩化物イオン濃度が全体的に小さくばらつきも大き いが，前垂れ下端高さがL.W.L.+0.0m，+0.5mのケースで 值が小さくなっていることが確認された.

\section{b) 潮位との関係}

本栈橋は，L.W.L.と H.W.L.の潮位差が約 $2 \mathrm{~m}$ ある.こ のことは，前垂れの設置高さが塩分供給量に与える影響 と密接に影響を与えるものと考えられる，そこで，横須 賀における 5 分ごとの観測潮位データ（2003年〜2011 年） を， $0.2 \mathrm{~m}$ 区間ごとの相対度数と累積相対度数に整理し たものが図-8 である.ここで，累積相対度数とは，前 垂れの下端が没水していた時間割合を示寸。この図より， 観測潮位の累積相対度数が，L.W.L.+1.5m 以浅では $0.0 \sim$ 0.3 とあまり前垂れ下端が没水しておらず，前垂れによ る短い周期の波の部分反射が有効に働かない. 一方，

L.W.L.+0.5m 以深では観測潮位の累積相対度数が $0.9 \sim 1.0$ とほとんどの時間で前垂れ下端が没水しており, 前垂れ による短い周期の波の部分反射が有効に働いていたと考 えられる。また，L.W.L.+1.0m では，観測潮位の累積相 対度数が 0.65 と観測期間の半分以上は前垂れの下端が 没水しているものの 0.35 もの時間は下端が没水してい ないことが理解できる. 図-7(a)前面梁において，前垂れ の設置高さが L.W.L.+1.0m のときに, 塩化物イオン濃度 にピークがみられた。これに対する明確な答えは持ち合 わせていないが，現地調査の際に目視した時の波向が海 から栈橋を見た場合に，まっすぐかやや左斜め方向から 栈橋に入射している状況であったことと，図-2 に見ら れるように, L.W.L.+0.5m と L.W.L.+1.0m の前垂れの間が 約 $2.0 \mathrm{~m}$ の開口部となっていることから, 左斜めから入 射した波が前垂れに遮られることなく, L.W.L.+1.0m の 供試体付近に伝達した可能性などが考えられる.

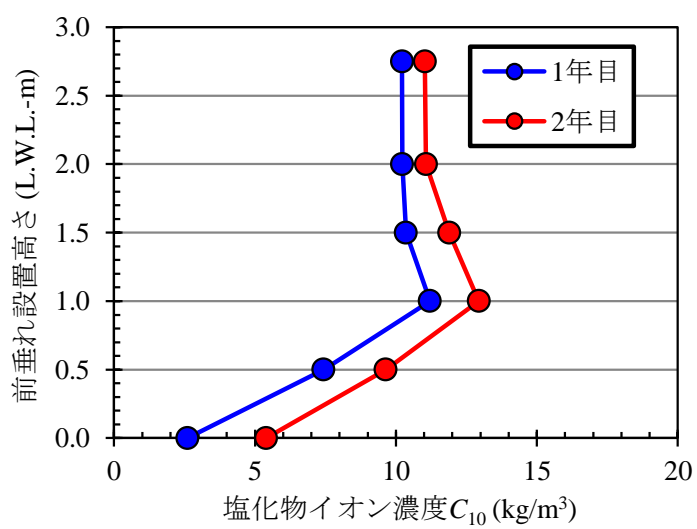

(a) 前面梁

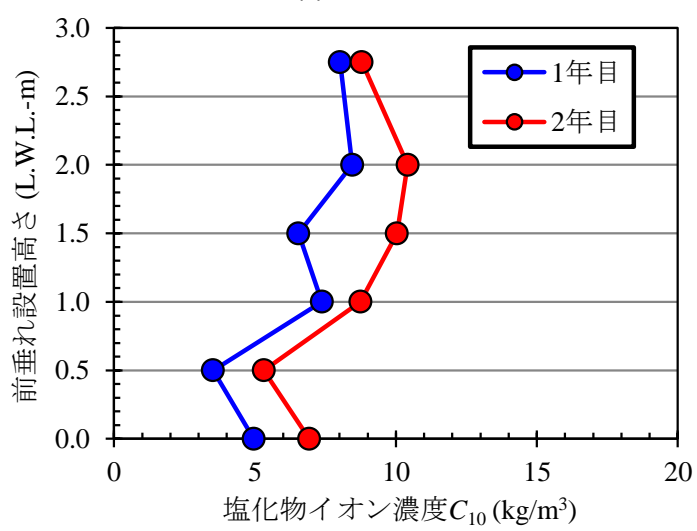

(b) 2 列目梁

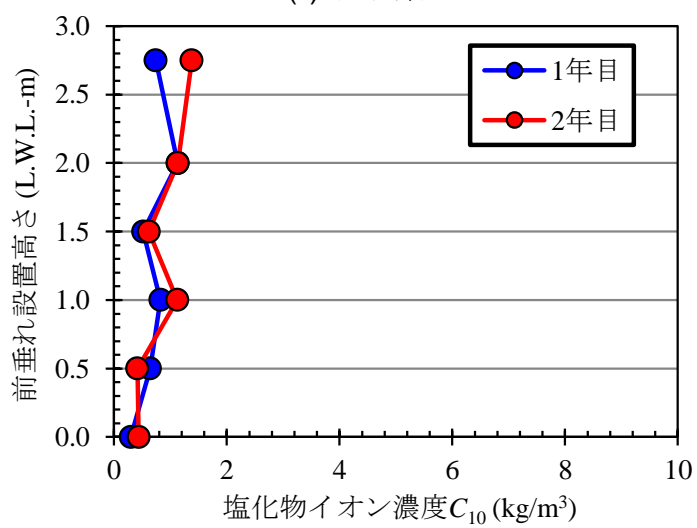

(c) 床版

図-7 前垂れ設置高さと塩化物イオン濃度

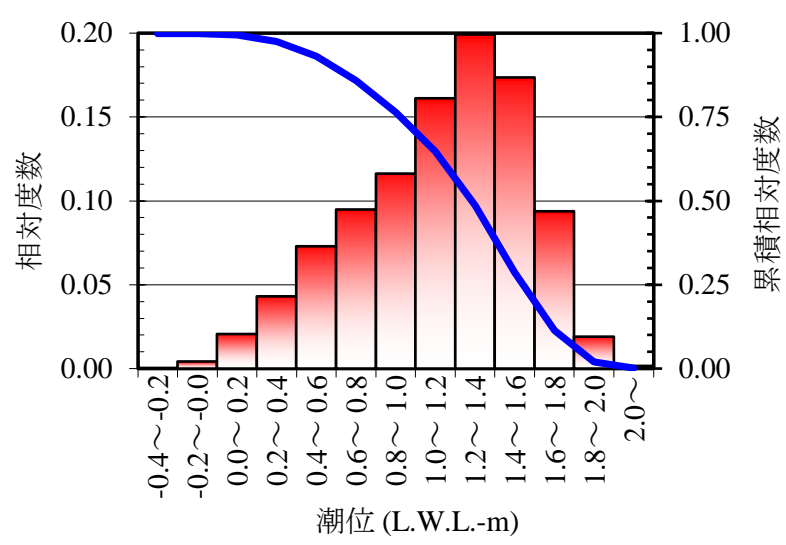

図-8 観測潮位の相対度数と累積相対度数 
これらを踏まえて，潮位の累積相対度数と塩化物イオ ン濃度の関係を図-9 に示すが，今回の実験の範囲では， 累積相対度数が概ね 0.8 より小さくなれば，前垂れ設置 による塩分供給量の低減効果が得られることが分かった.

\section{4. 前垂れの設置高さによる栈橋下の波浪諸元の 変化}

\section{(1) 波浪観測の概要}

前垂れの設置高さによって，栈橋下の波浪諸元がどの ように変化するかを調べるため, 図-2, 図-3の赤い三角 の位置の海底に水圧式波高計を設置（水深L.W.L.-0.75m） して，2012/9/15-11/29の期間における波浪観測を1時間に1 回の割合で実施した。サンプリング間隔 $0.05 \mathrm{~s} ， 1$ 回あた りの観測時間は20分とした．水圧式波高計を採用したの は，水深がL.W.L.-0.75m と極めて浅く超音波式波高計で は測定ができないこと，また容量式波高計の場合には， 漂流物や付着物の対策が必要でその結果計測する波浪が 変形する可能性があったことなどの理由による．ただし， 水圧式波高計の場合には，得られた水圧データから表面 波に適切に変換する必要があった.

\section{（2）水圧データから表面波への変換方法}

水圧データから表面波への変換は，文献》を参考に以 下の方法で行った。1回の観測で得られた水圧データ (24000個)は，ノイズの除去を行った後，最小二乗法によ る直線トレンドを除去して水圧変動データにした，その 後，フーリエ変換により周波数領域のデータに変換した のち，水圧の平均值より求めた水深に対応した波浪伝達 関数の逆数を各周波数に乗じた.ただし，深海波となる 短周期側の成分波の波浪伝達関数は，事前に造波水路で キャリブレーションを行い，観測時の水深で深海波とな る最小周期における波浪伝達関数を一定值で与えた．代 表的な水深における水圧式波高計で計測可能な最小周期 を表-2に示寸．また，潮位の違いによって，解析有効周

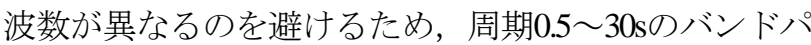
スフィルターを実施した．その後，逆フーリエ変換によ り表面波の水位変動データに変換し，ゼロダウンクロス 法で波別解析を実施した。

\section{（3） 波浪解析結果}

図-10に平均波高と平均波周期の相関図（L.W.L.+0.5m $-+2.0 \mathrm{~m})$ を示す．前垂れの設置高さによって平均波高 はほとんど変化しないが，平均波周期はL.W.L.+0.5m $の$ 方がL.W.L.+2.0mと比べて長い周期に変化している場合 が多くなっていることから，前垂れが深く根入れされて いる方が作用波浪の短周期成分が遮蔽され，栈橋下での
砕波の発生回数が減ったものと考えられる，その結果， コンクリート中への塩分供給量が低減されたと考えられ

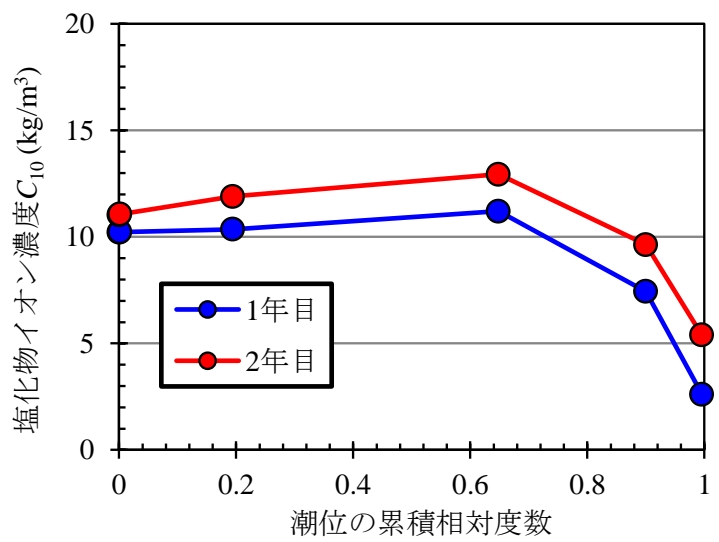

図-9 潮位の累積相対度数と塩化物イオン濃度（前面梁）

表-2 水圧式波高計で計測可能な最小周期 $T_{\text {min }}$

\begin{tabular}{c|c|c|c|c|c|c}
\hline $\begin{array}{c}\text { 水位 } \\
\text { の } \\
\text { 状態 }\end{array}$ & $\begin{array}{c}\text { 現地 } \\
\text { 潮位 } \\
(\mathrm{m})\end{array}$ & $\begin{array}{c}\text { 波高計 } \\
\text { 設置水深 } \\
(\mathrm{m})\end{array}$ & $\begin{array}{c}\text { 水深 } \\
h \\
(\mathrm{~m})\end{array}$ & $\begin{array}{c}\text { 周期 } \\
T_{\min } \\
(\mathrm{s})\end{array}$ & $\begin{array}{c}\text { 相対水深 } \\
h / L_{\min }\end{array}$ & $\begin{array}{c}\text { 波長 } \\
L_{\text {min }} \\
(\mathrm{m})\end{array}$ \\
\hline H.W.L. & 2.20 & -0.75 & 2.95 & 1.95 & 0.50 & 5.90 \\
M.S.L. & 1.10 & -0.75 & 1.85 & 1.54 & 0.50 & 3.70 \\
L.W.L. & 0.00 & -0.75 & 0.75 & 0.98 & 0.50 & 1.50 \\
\hline
\end{tabular}

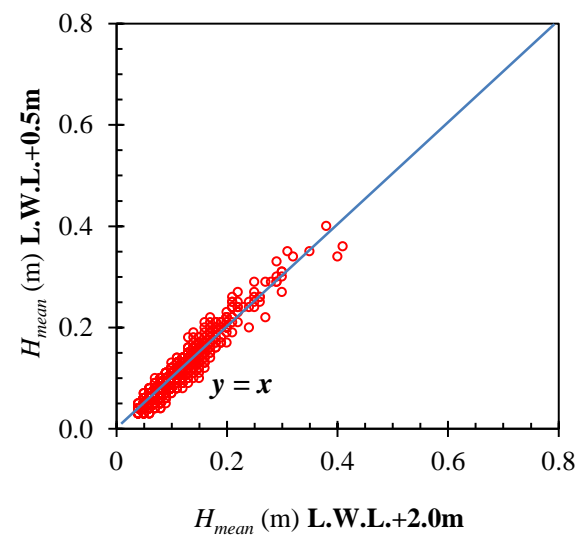

(a) 波高の比較

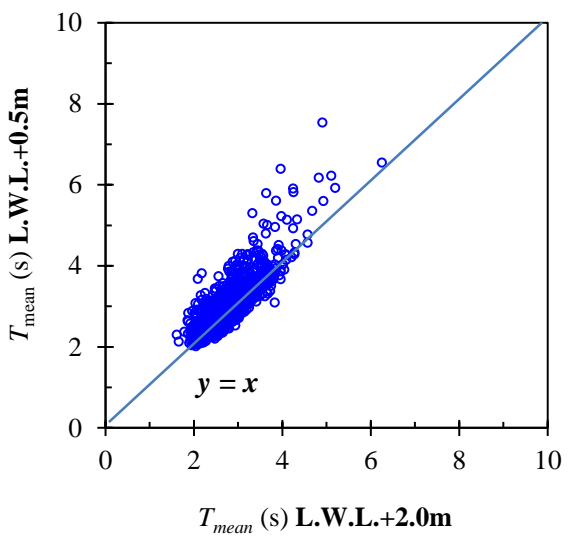

(b) 周期の比較

図-10 前垂れの設置高さによる波浪諸元の変化 
る.なお，森平ほが市のカーテン防波堤に関する規則波 の水理実験によると, 相対水深 $h / L(h:$ 水深, $L$ : 波の 波長）の増加にともない反射率も増加する傾向にあるが 今回対象とした前垂れの設置高さ付近 $(d / h=0, d:$ カー テンの没水深）における反射率は, 波形勾配 $H / L(H$ : 波高）にかかわらず概ね $210 \%$ 程度であった．ただし，前 垂れの没水深をより深く根入れすると反射波によって前 面の波高が増大寸るため, 固有振動周期の短い小型船舶 の利用が多い場所などでは，事前に没水深による波高増 大の影響を検討する必要があると考えられる。

\section{5. まとめ}

本研究では，実際の栈橋において，設置高さの異なる 前垂れを複数配置し，その背後に暴露したコンクリート 供試体の塩化物イオン濃度の測定結果から, 前垂れ設置 による塩分供給量の低減効果について検討を行った. また，前垂れ設置高さによる波浪の変化を取得するため, 栈橋下での波浪観測もあわせて行った，以下に，今回得 られた結論を示す。

今回の実験では，概ね L.W.L.+0.5m よりも前垂れの設 置高さを低くすると，塩化物イオン濃度が低減する傾向 が見られた．また，潮位と前垂れの設置高さの関係を検 討した結果, 前垂れの設置高さを, 潮位の累積相対度数 が 0.8 より小さくなる位置に設定すれば，塩分供給量の 低減効果が得られることが分かった。

栈橋下での波浪観測結果からは，今回の実験範囲では, 前垂れの設置高さによって平均波高はほとんど変化しな いが，平均波周期は L.W.L.+0.5m の方が L.W.L.+2.0m と
比べて長い周期に変化している場合が多くなっているこ とから，前垂れが深く根入れされている方が作用波浪の 短周期成分が遮蔽され，栈橋下での确波の発生回数が砕 波の発生回数が減ったものと考えられる. その結果, コ ンクリート中への塩分供給量が低減されていると考えら れる.

謝辞 : 本研究に当たり, 大阪市立大学大学院重松孝昌教 授から，大変有用な助言をいただいた。また，現地観測 では，東亜建設工業(株)技術研究開発センターの五十嵐 学氏, 宮崎哲史氏の両名には大変お世話になった. ここ に記して謝意を表す。

\section{参考文献}

1) 国土交通省: 平成 24年度国土交通白書, p. 113，2013.

2) 大即 信明, 原茂 雅光, 浜田 秀則: 栈橋コンクリー 卜上部工劣化実態概略調查報告，港湾技研資料， No. 617 , pp. 1-29, 1988.

3) 網野 貴彦, 大即 信明, 斎藤 豪, 羽㴊 貴士: 構造 形式や波の作用の影響を考慮した栈橋上部工部材の表面 塩化物イオン濃度の推定方法に関する提案，コンクリー 卜工学論文集, Vol.21, No.1, pp.1-11, 2010.

4) 森平 倫生, 柿崎 秀作, 合田 良実: カーテン防波堤 とその特性について，港湾技研報告，Vol. 3, No. 1, pp. 127, 1964.

5) 山路 徹: 海洋に位置するコンクリート構造物の耐久性 照査手法に関寸る研究, 港湾空港技術研究所資料, No. 1232, p. 50, 2011.

6) 国枝 稔, Kamal, A, 中村 光, Bruhwiler, E， : 超高強度 ひずみ硬化型セメント系材料の開発, コンクリート工学 年次論文集, Vol.29, No.1, pp.315-320, 2007

7) 財団法人沿岸開発技術研究センター: 沿岸波浪・海象観 測データの解析・活用に関する解説書, pp.43-46, 2001.

\title{
THE FIELD EXPERIMENT ON THE EFFECT OF REDUCING THE SALT SUPPLY TO THE PIER SUPERSTRUCTURE CONCRETE USING THE CURTAIN WALLS
}

\author{
Masahide TAKEDA, Kenichiro SHIMOSAKO, Toru YAMAJI, \\ Takashi HABUCHI, Takahiko AMINO, Daishin HANAOKA and Muneo TSUDA
}

It is a very important problem for maintenance of port and harbor structures that the reinforced concrete of superstructure on pier would be deteriorated from salt damage early on in many cases. In this study, some curtain walls that heights of the lower end were different from each other were hanged in front of superstructure on pier in operation for the purpose of reducing the number of occurrences of breaking waves under superstructure: the amount of generation of seawater spray. Concrete specimens that were installed to both beam and slab of superstructure behind curtain walls had been exposed to marine environment for one year or two years. According to chloride ion concentration measurement results of those specimens, the curtain wall reduced the amount of salt supply when its height of the lower end was lower than the height that was 0.8 of cumulative relative frequency of tidal height. 